\title{
Cancer Prevention Strategies for Nepal
}

\author{
Deepak Sundar Shrestha, ${ }^{1}$ Richard R. Love, ${ }^{2}$ Bishnu Dutta Paudel ${ }^{3}$ \\ 'Richa Bajimaya Memorial Foundation, Kathmandu, Nepal, ${ }^{2}$ Department of Computer Science, Marquette University, \\ Milwaukee, Wisconsin, U.S.A., ${ }^{3}$ Bhaktapur Cancer Hospital, Bhaktapur, Nepal.
}

\begin{abstract}
In Nepal, the commonest major malignancies and causes of cancer death are lung, cervix, stomach, breast, head and neck (lip, mouth, pharynx, larynx), gallbladder, ovary and liver. There are seven cancer-causative exposures which should be the focus of attention such as; tobacco smoking in $29 \%$ of men, and $6 \%$ of women, solid fuel burning in $69 \%$ of homes (multiple cancers), betel-nut chewing in $40 \%$ of men and $3 \%$ of women (head and neck cancers), alcohol abuse (liver and other cancers), Human Papilloma Virus (cervical cancer), Helicobacter pylori (stomach cancer) and Hepatitis B virus (liver cancer). To better address these reducible exposures, we suggest greater targeted strategies in three areas: Public health messaging for tobacco, solid-fuel burning, betel-nut, and alcohol; national policies for Hepatitis B virus vaccination; and analytic epidemiological and interventional research for Human Papilloma Virus and helicobacter.
\end{abstract}

Keywords: alcohol drinking; betel nut; helicobacter pylori; human papilloma virus; tobacco smoking.

\section{INTRODUCTION}

The major goals for cancer prevention in Nepal are similar to those among high-income countries, but there are major cancer-causing exposure differences, and social contexts, which, of necessity, should direct country-specific approaches. The goal of cancer prevention is to decrease premature mortality from malignancies by interventions which decrease incidence rates in middle-aged and young populations. Such interventions are primarily directed to decreasing critical exposures. ${ }^{1,2}$ This communication will first consider the useful descriptive and analytic epidemiology of cancer frequencies in Nepal and known causes and then propose targeted and prioritized messaging, public policy, and research approaches.

\section{SELECTED RELEVANT DESCRIPTIVE AND ANALYTIC EPIDEMIOLOGY FOR NEPAL}

The age pyramid for Nepal is striking for demonstrating the young age of the population, which circumstances have huge implications for allocations of efforts and resources in cancer prevention. ${ }^{3}$ Sixty and one-half percent of the population in 2019 was under age 30 $29.3 \%$ men and $30.2 \%$ women.

The descriptive epidemiology for major cancer case burdens and deaths is presented (Table 1 and 2.)

\begin{tabular}{|ll|}
\hline $\begin{array}{l}\text { Table 1. Major } \\
\text { 2020.4 }\end{array}$ & cancer cases projected for Nepal, \\
\hline Site & $\mathbf{n}(\%)$ \\
Lung & $2,505(12.2)$ \\
Cervix & $2,244(10.9)$ \\
Breast & $1,973(9.3)$ \\
Stomach & $1,552(7.6)$ \\
Head and neck & $1,274(6.2)$ \\
Gallbladder & $1,015(4.9)$ \\
Ovary & $594(2.9)$ \\
Liver & $524(2.6)$ \\
\hline
\end{tabular}

\begin{tabular}{|lc|}
\hline $\begin{array}{l}\text { Table 2. Nepal, percentages of all cancer deaths from } \\
\text { selected cancers. }{ }^{4}\end{array}$ \\
Site & $\mathbf{n}(\%)$ \\
Lung & 17.0 \\
Cervix & 11.0 \\
Stomach & 10.2 \\
Breast & 7.7 \\
Gallbladder & 5.5 \\
Head and neck & 5.1 \\
Liver & 3.7 \\
Ovary & 2.8 \\
\hline
\end{tabular}

Correspondence: Dr. Deepak Sundar Shrestha, Richa Bajimaya Memorial Foundation, Kathmandu, Nepal, Email: deepak@richafoundation.org.np, Phone: +977-9851175988. 
What is particularly striking are gender differences: incidence rates of stomach cancer are two-fold higher in men, those of gallbladder are two-fold higher in women, and those of liver are four-fold higher in men. ${ }^{4}$

Of these major cancers listed in tables 1 and 2, while the role of tobacco smoking in lung and head and neck cancers is well-known, the documented contributions of this exposure to increased risks for cancers of the stomach, cervix, breast, ovary, and gallbladder are less highlighted and discussed. . $^{5-10}$

The trends are for decreasing smoking in the last decade $(7-11 \%)$, but markedly so for women, so part of the lung and other cancer story in women can be from previously much higher rates of smoking. ${ }^{11,12}$ The smoking problem is compounded by the preponderance of data indicating that passive smoking-exposure to second-hand smoke-is associated with increased risk of lung and breast cancers. ${ }^{13}$

While for acute and chronic respiratory health reasons, there has been increased attention to the problem of solid fuel burning in $69 \%$ of Nepalese homes, the likely contribution of this home air pollution to lung cancer in women in particular has not been emphasized. ${ }^{14}$ Further compounding interpretation of the contributions of previous personal tobacco smoking, passive smoking, and home solid fuel- burning to lung cancer rates, is the uncertain, but strongly suspected contribution of general urban air pollution, particularly in the Kathmandu valley. ${ }^{15}$

Betel-nut chewing in various forms (particularly with tobacco as a PAAN) is associated with head and neck cancers of the lip, mouth, and pharynx. ${ }^{16}$ The prevalence of use rises from 23\% in men at age 20 to almost half of men in Nepal at age 50; in women the prevalence of use rises to $14 \%$ at age $50 .{ }^{17}$ Easy access and affordability currently, make this a serious problem.

Alcohol contributes significantly to the development of cancers of the liver, head and neck, esophagus, colon, and breast. ${ }^{18}$ In Nepal, recent data report that $38.6 \%$ of men, and $10.8 \%$ of women are current drinkers and $12 \%$ of men drink daily or almost daily, and engage in heavy episodic drinking. ${ }^{19}$

Human papilloma virus is clearly causative of cervical and head and neck cancers. ${ }^{20,21}$ A central role of Helicobacter pylori bacterial infection in stomach cancer is well described. ${ }^{22}$ Finally, the role of HBV infection in liver cancer is major. ${ }^{23}$

\section{PRIORITIZED PUBLIC HEALTH MESSAGING}

Maintaining good health is overwhelmingly based on what individuals do for themselves. The foregoing epidemiology summary makes very clear that the major cancer burdens and their causes in Nepal are unquestionably addressable by better targeted public health activities in messaging and public policy. The public can benefit from more and creative messaging in four key areas: tobacco, betel-nut chewing, alcohol and solid fuel burning in homes.

\section{TOBACCO}

Graphic warning labels on tobacco products have been consistently demonstrated to be effective in promoting quitting smoking, and in reducing initiation, especially with younger people, which situation is very relevant in Nepal (vide supra).24-26 Internationally, we have learned again some key lessons about public health messaging from the Covid pandemic: messages need to be consistent, repeated, and sensitive to equity issues. There are some areas for anti-tobacco messaging which have proven particularly effective (Table 3).

\begin{tabular}{l}
$\begin{array}{l}\text { Table 3. Suggested strongest types of messaging } \\
\text { about tobacco smoking. }\end{array}$ \\
\hline Focus areas for effective anti-tobacco messaging \\
Contents of cigarettes \\
Addiction from cigarettes \\
Suffering from cigarettes: Images of blackened \\
lungs, neck with tumors, facial deformities with \\
tumors, bones with holes from metastatic tumors \\
Vignettes of patients suffering \\
Social leaders speaking out against tobacco
\end{tabular}

\section{BETEL NUT CHEWING}

This culturally grounded common habit is notably more prevalent in lower socioeconomic groups, and is increasing in younger Nepalis. ${ }^{17,27,28}$ The themes effective in anti-tobacco messaging would seem to be potentially useful in public health messaging about this habit. In particular, imaging lip, mouth, and pharynx tumors and their treatment consequences might be expected to resonate with younger Nepalis.

\section{ALCOHOL ABUSE}

In Nepal, culturally, alcohol consumption has major roots in ethnic and religious traditions. These circumstances make potentially impactful messaging about alcohol a subject for careful research.

\section{Solid fuel-burning in homes}

There has simply not been enough public health attention and messaging about the pleomorphic adverse health consequences of solid fuel-burning 
which occurs in $69 \%$ of Nepali homes, and more frequently in rural communities. ${ }^{14}$ Women and children are disproportionately affected with pulmonary and cardiovascular chronic illnesses in addition to lung cancer from this exposure. Messaging themes focusing on children's health and gender equity may be notably effective.

\section{PUBLIC POLICY INITIATIVES}

\section{Tobacco}

Four strategies have been significantly successful in reducing tobacco smoking globally: ${ }^{24}$

1. Increases in excise taxes on tobacco.

2. Required graphic warning labels on tobacco packaging.

3. Banning of tobacco industry marketing. And

4. Smoke-free laws that prohibit smoking in public and workplaces.

Nepal has made strong commitments to tobacco control in signing, ratifying and formally becoming a party to the WHO Framework Convention on Tobacco Control (FCTC). The tobacco product (Control and Regulatory) Act 2011 is the primary law governing tobacco control in the country. Continued commitment to tobacco control is evident in the framework convention on tobacco control strategy 2030 which specifies:

- Strengthening the legislation and policy environment

- Use of tax to finance development innovations

- Strict enforcement of legal provisions on tobacco control

- Protection of people from exposure to tobacco smoke

- A ban on sales to and by minors

- Increases in tobacco taxes

- Effective enforcement and implementation of impactful packaging

- A comprehensive ban of tobacco advertising, promotion and sponsorship

- Creation of a supportive environment for a tobacco-free generation

- A comprehensive system to provide tobacco cessation support to public

- Preventing interference of the tobacco industry in policy development

- Integrating tobacco control as a priority agenda in other health and non-health initiatives

- Introducing tobacco control into school and university curriculum.

- Engagement of civil society in enforcing tobacco control laws

- Strong media engagement for advocacy and enforcement of laws and regulations and enhance awareness on danger of tobacco use

What is critical now is active pursuit of this strategy and these specific activities. We believe that in particular, greater fines for breaking the laws on sales, empowerment of broad civil societal groups in tobacco control, increasing the age for legal purchase of tobacco to 21, development of better age verification tools, and prohibition of tobacco product use in all forms of media should be considered.

\section{Betel-Nut chewing}

While betel nut chewing has long been a culturally acceptable practice for religious purposes, the majority of users seem to be unaware of its harmful effects. ${ }^{29}$ Strategies similar to those which have been so successful with tobacco noted above, need to be explored.

\section{Alcohol}

The WHO considers public policies in 3 areas related to alcohol to be among 16 Best Buys for prevention and control of noncommunicable diseases: i. Excise taxes on alcoholic beverages; ii. Bans on alcohol advertising; and iii. Restrictions on sales of alcoholic beverages..$^{30}$ Nepal needs additional laws addressing production and sales of locally brewed alcoholic beverages. Further educational efforts regarding the adverse health effects of alcohol are needed.

\section{Vaccination}

HBV: The estimated population Hepatitis B surface antigen seroprevalence is $2-4 \% .{ }^{31} A$ national hepatitis $B$ vaccination program among children was conducted in 2002-04, and in its evaluation, low rates of hepatitis $B$ infections were found in children before and after immunization. ${ }^{32}$ The government of Nepal, with the assistance of GAVI introduced Hepatitis $B$ vaccine from 2002 to 2004. It is currently administered as penta-valent vaccine along with Hemophilus influenza $\mathrm{B}(\mathrm{HiB})$ and Diphtheria Pertussis and Tetanus (DPT) vaccines at 6,10 and 14 weeks of age. Currently there is no policy for antibody titre testing and booster dose administration.

HPV: Globally, vaccination against Human Papilloma Virus has been proven to be an effective means to prevent cervical cancer. As tables 1 and 2 above indicate, cervical cancer is a major malignancy and cause of cancer death among Nepali women. There have been successful trial HPV vaccination programs in a few districts of Nepal, and there have been strong recommendations to implement HPV vaccination as part of regular immunization program. ${ }^{33,34}$ 


\section{ANALYTIC EPIDEMIOLOGIC AND IMPLEMENTATIONAL RESEARCH}

The two-fold higher rates of stomach cancer in men, and the two-fold higher rates of gallbladder cancer in women would seem to be appropriate questions to focus on in analytic epidemiologic studies.

Given the known major role for Helicobacter pylori in stomach cancer, investigation of population-based descriptive and analytic epidemiology and then pilot interventional studies addressing this infection are needed. ${ }^{35}$

\section{Funding}

Nepal is heavily dependent on international funding for health. Internationally, the epidemiologic transition to greater non-communicable disease (NCD) burdens in countries like Nepal is getting more attention, but NCDs are still way underfunded. Disease burdens (measured in disability associated life years, or DALYs) and international funding are not in synch: noncommunicable diseases, with half the DALYs burden, currently get less than two percentage of global health funding. ${ }^{36}$

\section{CONCLUSIONS}

Given the age pyramid in Nepal, a future-thinking approach to cancer in Nepal must focus on prevention. The role of both active and passive tobacco smoking in multiple major and common cancers needs to be part of public health messaging. More and stronger public health messaging about betel-nut chewing and home solid fuel burning is needed. Public policies must be developed to address also these two areas and HPV vaccination. The unfortunate circumstances of common stomach and gallbladder cancers should be the focus of collaborative international research activities.

\section{Conflict of Interest: None.}

\section{REFERENCES}

1. Institute of Medicine (US) and National Research Council (US) National Cancer Policy Board, Curry SJ, Byers T, Hewitt M. Fulfilling the potential of cancer prevention and early detection. Washington (DC): National Academies Press (US); 2003. [PubMed | Full Text | DOI]

2. Economist Intelligence Unit Limited. Breakaway: The global burden of cancer- Challenges and opportunities. [Internet]. Economist Intelligence Unit Limited. 2009. [cited 27 December 2021]. Available from: http://graphics.eiu.com/ upload/eb/EIU_LIVESTRONG_Global_Cancer_Burden. pdf. [Full Text]

3. Populationpyramid.net. Nepal 2019 [Internet]. Populationpyramid.net; 2019 [cited 4 August 2021]. Available from: https://www.populationpyramid.net/ nepal/2019/. [Full Text]

4. World Health Organization. Nepal Factsheet [Internet]. Geneva: World Health Organization; 2021 Mar [cited 2021 Aug 4]. 2p. Available from: https://gco.iarc.fr/today/data/ factsheets/populations/524-nepal-fact-sheets.pdf. [ [Full Text]

5. Praud D, Rota M, Pelucchi C, Bertuccio P, Rosso T, Galeone $\mathrm{C}$, et al. Cigarette smoking and gastric cancer in the Stomach Cancer Pooling (StoP) Project. Eur J Cancer Prev. 2018 Mar;27(2):124-33. [PubMed | Full Text | DOI]

6. Sugawara Y, Tsuji I, Mizoue T, Inoue M, Sawada N, Matsuo $\mathrm{K}$, et al. Cigarette smoking and cervical cancer risk: an evaluation based on a systematic review and meta-analysis among Japanese women. Jpn J Clin Oncol. 2019 Jan 1;49(1):77-86. [PubMed | Full Text | DOI]

7. Jones ME, Schoemaker MJ, Wright LB, Ashworth A, Swerdlow AJ. Smoking and risk of breast cancer in the Generations Study cohort. Breast Cancer Res. 2017 Nov

\section{2;19(1):118. [ PubMed | Full Text | DOI]}

8. Fonseca-Moutinho J. Smoking and Cervical Cancer. ISRN Obstetrics and Gynecology. 2011;2011:1-6. [PubMed I Full $\underline{\text { Text }} \mid \underline{\mathrm{DOI}}]$

9. Lugo A, Peveri G, Gallus S. Should we consider gallbladder cancer a new smoking-related cancer? A comprehensive meta-analysis focused on dose-response relationships. Int J Cancer. 2020 Jun 15;146(12):3304-11. [PubMed | Full Text | DOI]

10. Tamrakar D, Paudel I, Adhikary S, Rauniyar B, Pokharel P. Risk Factors for Gallbladder Cancer in Nepal a Case Control Study. Asian Pac J Cancer Prev. 2016;17(7):3447-53. [PubMed [ Full Text]

11. Shrestha N, Mehata S, Pradhan PMS, Joshi D, Mishra SR. A nationally representative study on socio-demographic and geographic correlates, and trends in tobacco use in Nepal. Sci Rep. 2019 Feb 25;9(1):2682. [PubMed | Full Text | DOI]

12. World Health Organization. WHO global report on trends in prevalence of tobacco use 2000-2025 [Internet]. Geneva:World Health Organization; 2019 [cited 4 August 2021]. Available from: https://www.who.int/docs/default-source/searo/ tobacco/country-fact-sheets/nepal-who-tobacco-prevalence-trend-estimates-2019.pdf?sfvrsn=57666918_2. [ [ Full Text]

13. Kim AS, Ko HJ, Kwon JH, Lee JM. Exposure to Secondhand Smoke and Risk of Cancer in Never Smokers: A Meta-Analysis of Epidemiologic Studies. Int J Environ Res Public Health. 2018 Sep 11;15(9):1981. [PubMed | Full Text I DOI]

14. Paudel D, Jeuland M, Lohani S. Cooking-energy transition in Nepal: trend review. Clean Energy. 2020;5(1):1-9. [Full Text I DOI] 
15. Saud B, Paudel G. The Threat of Ambient Air Pollution in Kathmandu, Nepal. J Environ Public Health. 2018 Jul

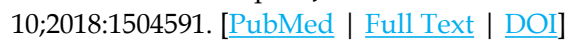

16. Niaz K, Maqbool F, Khan F, Bahadar H, Ismail Hassan F, Abdollahi M. Smokeless tobacco (paan and gutkha) consumption, prevalence, and contribution to oral cancer. Epidemiology and Health. 2017;39:e2017009. [PubMed | $\underline{\text { Full Text } \mid \text { DOI] }}$

17. Sinha DN, Bajracharya B, Khadka BB, Rinchen S, Bhattad VB, Singh PK. Smokeless tobacco use in Nepal. Indian Journal of Cancer. 2012;49(4):352. [Full Text | DOI]

18. Brown LM. Epidemiology of alcohol-associated cancers. Alcohol. 2005 Apr;35(3):161-8. [라bMed | Full Text | DOI]

19. Public Health Update. Nepal STEPS Survey 2019 Alcohol Consumption and Policy Fact Sheet [Internet]. Nepal: Public Health Update; 2020 Sep 29 [cited 2021 Aug 4]. Available from: https://publichealthupdate.com/nepal-steps-survey-2019-alcohol-consumption-and-policy-fact-sheet/. [ [Full Text]

20. World Health Organization. IARC Monographs on the Evaluation of Carcinogenic Risks to Humans [Internet]. Geneva: World Health Organization; 2005 Feb [cited 2021 Aug 4]. Available from: https://monographs.iarc.who.int/ wp-content/uploads/2018/06/mono90.pdf. [Full Text]

21. D'Souza G, Dempsey A. The role of HPV in head and neck cancer and review of the HPV vaccine. Prev Med. 2011 Oct;53 Suppl 1(Suppl 1):S5-S11. [라Med | Full Text | DOI]

22. Crowe SE. Helicobacter pylori Infection. N Engl J Med. 2019 Mar 21;380(12):1158-65. [uuㄹ | Full Text | DOI]

23. Franco E, Bagnato B, Marino MG, Meleleo C, Serino L, Zaratti L. Hepatitis B: Epidemiology and prevention in developing countries. World J Hepatol. 2012 Mar 27;4(3):74-80. [P | Full Text | DOI]

24. Kamaraju S, Drope J, Sankaranarayanan R, Shastri S. Cancer Prevention in Low-Resource Countries: An Overview of the Opportunity. Am Soc Clin Oncol Educ Book. 2020 Mar;40:1-12. [ㅁubMed | Full Text | DOI]

25. O'Hegarty M, Pederson LL, Nelson DE, Mowery P, Gable JM, Wortley P. Reactions of young adult smokers to warning labels on cigarette packages. Am J Prev Med. 2006 Jun;30(6):467-73. [․ㅏbMed | Full Text | DOI]

26. Wakefield M, Coomber K, Zacher M, Durkin S, Brennan E, Scollo M. Australian adult smokers' responses to plain packaging with larger graphic health warnings 1 year after implementation: results from a national cross-sectional tracking survey. Tob Control. 2015 Apr;24(Suppl 2):ii17-ii25. [PubMed | Full Text $\mid \underline{\text { DOI] }}$
27. Sinha DN, Gupta PC, Kumar A, Bhartiya D, Agarwal N, Sharma S, et al. The Poorest of Poor Suffer the Greatest Burden From Smokeless Tobacco Use: A Study From 140 Countries. Nicotine Tob Res. 2018 Nov 15;20(12):1529-32. [PubMed | Full Text | DOI]

28. Sinha DN, Kumar A, Bhartiya D, Sharma S, Gupta PC, Singh H, et al. Smokeless Tobacco Use Among Adolescents in Global Perspective. Nicotine Tob Res. 2017 Nov 1;19(11):1395-6. [PubMed | Full Text | DOI]

29. Basnet BB, Sharma KR. Perceived Benefits, Knowledge about Cancer and Attitude towards Promotion of Gutkha Amongst Gutkha users from Nepal. Birat Journal of Health Sciences. 2019;4(1):592-5. [Full Text | DOI]

30. World Health Organization. Time to deliver: report of the WHO Independent high-level commission on noncommunicable diseases [Internet]. Geneva: World Health Organization; 2018 [cited 2021 Aug 4]. 44p. Available from: https://apps.who.int/iris/handle/10665/272710. [Full Text]

31. Ott JJ, Stevens GA, Groeger J, Wiersma ST. Global epidemiology of hepatitis B virus infection: new estimates of age-specific HBsAg seroprevalence and endemicity. Vaccine. 2012 Mar 9;30(12):2212-9. [PubMed | Full Text | DOI]

32. Upreti SR, Gurung S, Patel M, Dixit SM, Krause LK, Shakya $\mathrm{G}$, et al. Prevalence of chronic hepatitis B virus infection before and after implementation of a hepatitis B vaccination program among children in Nepal. Vaccine. $2014 \mathrm{Jul}$ 23;32(34):4304-9. [라bMed | Full Text | DOI]

33. Singh Y, Shah A, Singh M, Verma S, Shrestha BM, Vaidya $P$, et al. Human papilloma virus vaccination in Nepal: an initial experience in Nepal. Asian Pac J Cancer Prev. 2010;11(3):615-7. [PubMed | Full Text]

34. Bruni L, Albero G, Serrano B, Mena M, Collado JJ, Gomez D, et al. Human Papillomavirus and Related Diseases Report [Internet]. Barcelona: HPV Information Centre; 2021 Oct 22 [cited 2021 Aug 4]. 164p. Available from: https:/ / hpvcentre. net/statistics/reports/NPL.pdf. [Full Text]

35. Renaissance School of Medicine Stony Brook University. Causes \& Prevention of Stomach Cancer among Himalayan People in Nepal [Internet]. New York: Renaissance School of Medicine Stony Brook University [cited 2021 Aug 5]. 12p. Available from: https://renaissance.stonybrookmedicine. edu/sites/default/files/Proposal_Causes \% 20and $\% 20$ Prevention \% 20 of \% 20 Stomach \% 20 Cancer_ May\%201\%2C\%202019.pdf. [Full Text]

36. Enserink M. After the windfall. Science. 2014 Sep 12;345(6202):1258-9. [PubMed | Full Text | DOI]

This work is licensed under a Creative Commons Attribution 4.0 International License. The images or other third party material in this article are included in the article's Creative Commons license, unless indicated otherwise in the credit line; if the material is not included under the Creative Commons license, users will need to obtain permission from the license holder to reproduce the material. To view a copy of this license, visit http://creativecommons.org/licenses/by/4.0/ 